\title{
Education and Research at the Paediatric Hospitals
}

The founders of paediatric hospitals intended their institutions to serve for the education and training not only of doctors and medical students, but also of nurses and parents. During the nineteenth century the training of nurses proved to be the most successful aspect of the overall mission. Necessity was a potent stimulant for, as we have seen, the children's hospitals could not function properly with only casual nursing services. Furthermore the creation of these institutions coincided with the era of nursing reform, making it easier for management committees to launch their own training schemes. But change was not simply imposed from above. To get the service they wanted management committees had to negotiate with women of the higher social classes who volunteered to reorganize nursing in exchange for extensive freedom from interference. Thus nurses acquired their own leaders who believed that improved training and discipline should be rewarded with greater responsibility for nurses, sisters and superintendents. The founders' desire for better educated nurses was realized but lady superintendents and matrons would play a far larger part in organizing training programmes than ever anticipated by the original medical and lay planners. The hospital medical staff had expected to be in charge of nursing, as was traditional, but found instead that the new nursing orders demanded a considerable degree of self government.

The training of nurses at Great Ormond Street began inauspiciously. In 1856 the committee of management announced that the hospital was prepared to receive young women for instruction. The aim was not to prepare trainees for careers as hospital nurses, but to teach privately employed nursery maids the art of handling sick children. ${ }^{1}$ Lady employers were not impressed, or could not spare the services of their children's caretakers, for not a single application was received during the first year. ${ }^{2}$ By this time the hospital was in serious financial straights with capital, as indicated by Jules Kosky, reduced to less than a thousand pounds. ${ }^{3}$ The situation was saved by Charles Dickens who consented to chair the annual dinner of February 1858. He was the main speaker and his eloquence released such a liberal response (Kosky reports that the dinner raised $£ 2,850$ ) that the committee of management was subsequently not only able to increase the number of occupied hospital beds from 30 to 44 but also to purchase an adjoining house and garden, 48 Great Ormond Street. ${ }^{4}$ A portion of the new space was set apart as a nurses' home in the hope that residential accommodation would entice young women to apply for training in the nursing of children.

The ground floor section of the new property was dedicated as an infant nursery, the mid-nineteenth-century equivalent of a modern day care centre. Much of the initiative for

1 Fourth Annual Report of the Hospital for Sick Children (London, 1856), p. 7.

2 Fifth Annual Report of the Hospital for Sick Children (London, 1857), p. 6.

3 Jules Kosky, Mutual Friends: Charles Dickens and Great Ormond Street Hospital (London: Weidenfeld and Nicolson, 1989), p. 186.

${ }^{4}$ For fascinating details about the 1858 dinner and the speech and reading by Dickens, see Kosky, Mutual Friends, pp. 183-203. 


\section{Education and Research at the Paediatric Hospitals}

this progressive venture came from Charles West who had observed the utility and success of crèches as first established in France by Firmin Marbeau, one of the mayors of Paris, in $1844 .^{5}$ The nursery was intended for the daytime reception of the children of poor married women under the age at which they were admitted into infant schools, i.e. under the age of three. The mothers had to bring a recommendation from an employer, clergyman or householder plus their marriage certificate. The charge was $2 \mathrm{~d}$. a day for babies under eight months and 5d. a day for older children. Each child was expected to be healthy, clean and properly dressed, vaccinated against smallpox, and not in contact with anyone suffering from measles, scarlet fever or smallpox. In part, as with the French crèches, the nursery was intended to ensure the good care of infants whose mothers went out to work. But also it was envisioned as an educational project, to instruct parents, nurses and other young women (such as the aforementioned girls from Louisa Twining's nearby Industrial Home) in the day to day management of small children to maintain and promote good health.

Initially the day nursery flourished while the training of nursemaids continued to languish. In 1860 the committee of management was complaining 'that at present scarcely any young women have availed themselves of the opportunity which the Hospital and Nursery could afford them, of obtaining experience in the care and management of children. ${ }^{6}$ To encourage trainees, it was proposed to receive them without fee, and to provide board and lodging for $6 \mathrm{~s}$. a week. Nevertheless, during the early sixties, even the modest aim of two months training for private children's nurses was not realized, because most working-class girls were deterred by an expenditure of $6 \mathrm{~s}$. a week for experience not perceived as essential for later employment. Their perceptions were correct since employers neither required hospital experience nor were willing to pay for their already hired nursemaids to receive training.

Although apparently popular with parents and with visitors, the day nursery was closed in 1864 to make room for convalescent patients. By now other day nurseries were being instituted in the metropolis, and the committee of management considered that Great Ormond Street should concentrate on its prime mandate of caring for the sick. ${ }^{7}$ On the other hand the number of pupil nurses was gradually increasing perhaps, as believed by the management committee, because of greater efficiency in training since the introduction of a lady superintendent late in 1862. Nevertheless, systematic instruction for hospital nurses, as opposed to the briefer and more casual training of nursemaids, did not really get under way until after the opening of the new hospital in 1875 and more particularly the appointment of Catherine Wood as lady superintendent in 1878.

The children's hospitals accepted trainees at a younger age, twenty or twenty-one years, than the general hospitals that usually set a minimum age of twenty-five years. At the Alexandra Hospital for Children with Hip Disease girls only eighteen years old could apply for training. Younger probationers were encouraged at the paediatric hospitals because it was thought that they would be more understanding of children and also that the work was less strenuous than in hospitals with adult patients. Nevertheless, the trainees were usually expected to be on the wards, or at lectures, for fourteen hours a day, with only

${ }_{6}^{5}$ Margaret Hewitt, Wives and Mothers in Victorian Industry (London: Rockliff, 1958), pp. 155-6.

${ }_{7}^{6}$ Eighth Annual Report of the Hospital for Sick Children (London, 1860), p. 7.

${ }^{7}$ Thirteenth Annual Report of the Hospital for Sick Children (London, 1865), pp. 6-7. 
about three or four hours off duty each day. ${ }^{8}$ Apart from ad hoc training on the wards, lectures on anatomy and physiology were usually given by members of the medical staff, and instruction on nursing and cookery by the matron and senior nursing staff. Great Ormond Street required two years of training and the passage of a final examination for nursing credentials (only eighteen months for special probationers), but by the early twentieth century had extended the training period to three years. The long hours of work, meagre salaries, and brief vacations (three to four weeks per year) must have ensured, as they were intended, that only dedicated young women survived and prospered.

As far as the training of physicians was concerned, Great Ormond Street initially advertised that it was open to visits by any medical persons who needed only to introduce themselves on arrival. ${ }^{9}$ Regular attendance for six months was charged a fee of 5 guineas but so poor was the response that by 1856 charges had been reduced to 3 guineas. ${ }^{10}$ In spite of such unpromising auspices, in November, 1859, the medical staff at Great Ormond Street introduced a course of lectures, one per week, on the diseases of children for medical practitioners and students. ${ }^{11}$ The lectures were advertised in the medical journals; admission was free but medical students required a letter of recommendation from one of their teachers. West gave the first lectures, followed by William Jenner, and the surgeon, Athol Johnson, completed the course. The following summer a second series was organized on similar lines, except that a registration fee of half a guinea was now required from medical practitioners. Courses of lectures became a permanent feature at Great Ormond Street in spite of often disappointing attendance.

By the early 1870s Great Ormond Street had annulled all fees for medical student attendance on the wards and at the outpatients department. The aim was to encourage students to sign up as clerks or assistants to the house officers, but the response was meagre, perhaps understandably so since knowledge of the diseases of children was not required by London medical examiners. According to West, attendance at a children's hospital was usually undertaken after qualification, when a doctor was 'seeking to supplement his general knowledge by special study'. ${ }^{12}$ For those who could forego paid employment for a while, a few months attendance at a paediatric hospital would provide invaluable experience for a later career in general practice.

In the late $1880 \mathrm{~s}$, however, medical students began to display greater enthusiasm for taking up clerkships and attending lectures and clinics. This came about because of the establishment of the Conjoint Board Examination in 1884 by the Royal College of Physicians of London and the Royal College of Surgeons of England. To receive the double qualification of Licentiate of the Royal College of Physicians and Member of the Royal College of Surgeons, which allowed the recipient to practise medicine anywhere in the United Kingdom, a candidate was required to produce evidence of having discharged the duties of clinical clerk for six months, and of surgical dresser for another six months,

\footnotetext{
${ }^{8}$ Select Committee on Metropolitan Hospitals 1890-1893, Third Report, B.P.P. 1892, XIII, Appendix, pp. 56-7.

9 'Hospitals and Schools for Special Medical Instruction in the Metropolis', Lancet, ii (1852): 312.

${ }^{10}$ Ibid., and Lancet, ii (1856): 342.

11 Great Ormond Street Archives (hereafter G.O.S. Archives), Medical Committee Meeting, 31 August, 1859.

12 Charles West, On Hospital Organisation, with Special Reference to the Organisation of Hospitals for Children (London: Macmillan, 1877), p. 70.
} 


\section{Education and Research at the Paediatric Hospitals}

at a recognised general hospital, infirmary, or dispensary. ${ }^{13}$ Great Ormond Street qualified as a training site and by the 1890 s about 50 students per year were attending as clerks or dressers. The appointments usually lasted for three months, for which the student was charged a fee of 2 guineas to the benefit of the instructors. ${ }^{14}$ Now also the hospital encouraged women to take up clerkships allowing up to half the total number to be occupied by female medical students. By the end of the century, the East London Hospital for Children, the Evelina, the North Eastern Hospital for Children, and the Victoria Hospital for Children, were also approved sites for the clinical training of medical students.

By this time clinical clerkships at approved hospitals were essential to qualify not only for the conjoint examinations but also for the final examinations of the University of London. However, for the duration of the nineteenth century, knowledge of the diseases of children was not tested in the qualifying examinations, nor at those given by the Universities of Oxford and Cambridge. Matters were seen differently in the provinces where the Victoria University (then comprised of colleges at Manchester, Liverpool and Leeds) included diseases of children as a subject for the final examination, and the University of Durham required 'diseases of women and children', presumably with greater emphasis on illness in the newborn than in older children. In Scotland, the University of St. Andrews examined students in paediatrics, but not the Universities of Edinburgh and Glasgow where however, as in London, children's hospitals were one of the many sites where clerkships and dresserships could be held. The staff of the Children's Hospital at Edinburgh gave classes on the diseases of children (considered as a special non-qualifying subject) to women medical students separately from the male students, and the university considered paediatrics important enough to appoint a lecturer to co-ordinate the courses. ${ }^{15}$

The other oft reiterated mission of the new hospitals was to advance medical knowledge. Most institutions prominently displayed a statement to this effect in their annual reports, although there is much evidence that for management committees this objective was a minor consideration compared to those of providing treatment for sick children and of training competent nurses. Nor was this surprising since research reports were not the kind of material likely to stimulate donors to further generosity. Furthermore, as has been pointed out by W. F. Bynum, anti-vivisectionists were most vocal and powerful in Britain, and repeatedly critical of animal experimentation as carried out on the Continent. ${ }^{16}$ Those who objected to research on animals were likely to oppose the use of children, especially sick children, as 'guinea-pigs'. ${ }^{17}$ So management committees tended to discourage potentially risky experimental procedures, and even frowned upon the

\footnotetext{
13 'Regulations of the General Medical Council and Medical Licensing Bodies', British Medical Journal, ii (1885): 475-81.

${ }_{15}$ Second Report . . on Metropolitan Hospitals, B.P.P., 1890-1, XIII, para. 20299-306.

15 'Regulations', Lancet, ii (1899): 628-38.

16 W. F. Bynum, Science and the Practice of Medicine in the Nineteenth Century (Cambridge: University Press, 1994), p. 169. The standard study of the anti-vivisection movement in Britain is Richard D. French, Antivivisection and Medical Science in Victorian Society (Princeton: University Press, 1975).

${ }^{17}$ For a discussion of this association see, for example, Mary Ann Elston, 'Women and Anti-vivisection in Victorian England, 1870-1900', in Nicolaas A. Rupke (ed.), Vivisection in Historical Perspective (London: Croom Helm, 1987), pp. 259-94.
} 


\section{Elizabeth M. R. Lomax}

medical habit of admitting interesting cases ahead of those bearing subscribers' letters of recommendation. In any case research had not yet proved of obvious value to anyone except those medical men who visualised the exercise as a source of personal satisfaction, professional advancement, and the only means of providing enlightenment on the causes and treatment of most illness among children.

Managerial dislike of medical activism in research seems to have played a part in Dr. Humphreys' dismissal from Pendlebury Hospital in 1879. In a letter to the British Medical Journal defending the hospital's action, Edward Cross, chairman of the committee of management, stated that 'The Board of Governors discovered, very soon after Dr. Humphreys' appointment, that a medical investigator and experimentalist, however accomplished, was not necessarily gifted with energy or judgment, nor fitted for a position requiring such qualities'. ${ }^{18}$ Humphreys had presented papers to the microscopical section of the Manchester Medical Society and, according to Dr. Henry Simpson, president of the Manchester Medico-Ethical Association, had 'shown marked ability in the pursuit of medicine as a science'. ${ }^{19}$ Simpson, who backed Humphreys unreservedly in the controversy, also stated that the history of the Children's Hospital was 'distinguished by this peculiar feature, that during its long period of existence it had added next to nothing to medical science and literature'. Apart from some papers contributed by Dr. Barlow, Simpson was not aware of any scientific work 'emanating' from Pendlebury. Possibly his criticism rankled, for a couple of years later was published the first of annual reports of selected cases: Abstracts of some of the Medical and Surgical Cases treated at the General Hospital for Sick Children, Pendlebury, Manchester, during the year 1881. These reports were descriptive rather than analytical but allowed for far greater clinical detail than was possible in the annual reports of the hospital.

Judging from nineteenth-century references and bibliographies, more research was prosecuted in France and in German countries, where paediatrics was more explicitly recognised as a speciality. Using late-nineteenth-century American paediatric texts as reasonably impartial sources of references to the European medical literature, one finds German papers to be those most frequently quoted, followed by French and British ones in about equal proportion, even though some bias probably existed in favour of those written in the English language. L. Emmett Holt's renowned Diseases of Infancy and Childhood, first published in 1897, contained about 35 references (as footnotes) to the German literature, 22 to the French, and 21 to the British, where a greater proportion might have been expected owing to the common language. Research was more extensive on the Continent because paediatrics was accepted as a special and pertinent subject earlier there than in England. Vienna was the first university to appoint a professor ordinarius of paediatrics, Hermann Widerhofer, in 1884, although twenty years earlier Gottfried Ritter von Rittershain became professor extraordinarius of paediatrics at Prague and Eduard $\mathrm{H}$. Henoch had a similar appointment in Berlin as early as $1858 .{ }^{20}$ Marie Jules Parrot was

\footnotetext{
18 Edward Cross, 'The Manchester Children's Hospital and Dr. Humphreys', British Medical Journal, i (1880): 186.

19 Manchester Medico-Ethical Association, Dr. Humphreys and the Children's Hospital, Pendlebury (Manchester, 1880), p. 6.

20 Angel Ballabriga, 'One Century of Pediatrics in Europe', in B. L. Nichols, A. Ballabriga, and N. Kretchmer (eds), History of Pediatrics 1850-1950 (New York: Raven Press, 1991), pp. 1-21; Fielding H. Garrison, 'History of Pediatrics', in Isaac A. Abt (ed.), Abt-Garrison History of Pediatrics (Philadelphia: W. B. Saunders, 1965), p. 96.
} 


\title{
Education and Research at the Paediatric Hospitals
}

appointed professor of medical history in Paris in 1876, only to become professor of clinical paediatrics three years later. By the end of the century many continental universities had one or more chairs of paediatrics whereas none was created in Britain until after the First World War. In 1906 King's College, London, had appointed George Frederick Still as honorary professor of the diseases of children, but this was a college rather than a university professorate, and unsalaried. ${ }^{21}$

Paediatrics was perceived by many British physicians as general medicine practised on young patients rather than a special subject in its own right. Even doctors who worked in children's hospitals sometimes voiced doubts as to the need for this kind of institution. Samuel Gee expressed such sentiments to members of the British Medical Association, oddly enough, at the inauguration of the Section for Diseases of Children in 1883:

\begin{abstract}
But art is not yet so vast, nor human wit so narrow, that the diseases of children need be made a speciality; and I believe that none of us are specialists in the popular and evil sense of the word. For my own part, if I may speak so much of myself, being physician to a hospital for children, and to a much greater hospital for people of all ages, I can see that my knowledge of children's diseases would be much poorer and meaner than it is, were it not for the larger experience I gain at St. Bartholomew's. I wish that the governors of the general hospitals would make more provision for sick children, and then the need for special children's hospitals would pass away. ${ }^{22}$
\end{abstract}

With such ambivalence as to the merits of paediatrics as a speciality even on the part of its practitioners, it is not surprising that no dedicated societies emerged during the nineteenth century, apart from the above mentioned Section for the Diseases of Children for members of the British Medical Association, and this would only meet sporadically until the 1890s. The same lack of commitment prevented the emergence of special journals until 1896, when Pediatrics appeared on the scene as an Anglo-American enterprise published simultaneously in London and New York. The American edition did well but the English one collapsed after two years due to insufficient funding. However the editor, George Carpenter, then attending physician at the Evelina, persisted and established the British Journal of Children's Diseases, first published in 1904, on a more permanent financial basis. $^{23}$

In Britain research in the diseases of children was also at a disadvantage as compared to that in other disciplines, such as surgery, dermatology, urology, diseases of women, and ophthalmology. In the first place, management committees of children's hospitals were not initially keen to spend money on any extra equipment or staff that might be needed since, in their opinion, patient care was the overriding function of the institutions they managed with hard to find resources. More critically, hospital physicians themselves had mixed feelings about the relevance of paediatrics to their future careers since it was not an established speciality during the nineteenth century, in the usual sense of spawning its own societies, journals, and teaching appointments at medical schools. Conditions were more

${ }^{21}$ Before World War I at London professors were appointed and paid by the colleges and schools; a formal University professoriate was gradually formed after the war, Negley Harte, The University of London 1836-1986 (London: Athlone Press, 1986), p. 198.

${ }^{22}$ Samuel Gee, 'A Survey of the Literature of the Diseases of Children', British Medical Journal, ii (1883): 236-8.

${ }^{23}$ George Carpenter, 'Introductory', British Journal of Childen's Diseases, 1 (1904): 1-3. 
favourable on the Continent, as intimated above, but even there paediatrics was a latecomer to the speciality scene. According to Ballabriga, paediatrics was not officially included in Austrian medical curricula until 1899, and not in German ones until 1918. ${ }^{24}$ From its inception the Enfants Malades Hospital in Paris had been used for clinical teaching, 'complementary' courses in paediatrics were organized after 1862, but attendance by medical students was elective until 1893 when paediatrics became compulsory for qualification in Paris. However, the smaller British paediatric hospitals were even more isolated from the mainstream of academic medicine, at least until after 1884 when interested medical students could gain credit from attending on the wards and in clinics. But apart from a lectureship at Victoria University instituted in 1880 and first held by Henry Ashby, university appointments in the diseases of children were not available in England during the nineteenth century.

Lacking the usual fora for professional exposure, that is specialized society meetings and associated journals, or teaching appointments, hospital doctors had little incentive to spend precious time on research apart from that which emerged naturally from their duties as clinicians, surgeons or macro-pathologists. With the exception of Charles West, Eustace Smith, and a few others who became full-time paediatricians, the senior medical staff in paediatric hospitals also had other commitments, often perceived as more important. Since their hospital appointments were honorary, their source of income was private practice where the care of adults could be far more remunerative than that of children. Some, for example John Welch and Annie Clark at Birmingham, earned their living through general practice. The more ambitious sought appointments in the large, general hospitals and their associated medical schools, where they were ensured of professional exposure and, if considered successful, of lucrative private practice and even the later reward of knighthood. When well launched, a few resigned their appointments at the paediatric hospitals. According to Thomas Barlow's biographers, the pressure of practice 'obliged him to relinquish his post at Great Ormond Street' in 1899, by which time he was also a full physician at University College Hospital, professor of clinical medicine, and physician extraordinary to Queen Victoria. ${ }^{25}$ The following year he was made a baronet. William Jenner resigned from Great Ormond Street in 1862, one year after being appointed Physician-Extraordinary to the Queen. However, he became consulting physician not only to Great Ormond Street but also to the Victoria Hospital for Sick Children upon its inception in 1866 which appointments, although not onerous, suggest a continuing interest in paediatrics. Two years later Jenner was made a baronet. Timothy Holmes, became assistant surgeon at Great Ormond Street in 1859, and full surgeon in 1861. The same year he was appointed assistant surgeon at St. George's Hospital, where previously he had been student, house surgeon and surgical registrar, and was promoted to full surgeon in 1867. In May, 1868, he resigned his appointment at Great Ormond Street. Before resignation he seems to have shirked his duties at the Children's Hospital for the following entry was made in March by one of the visiting governors, Hall Plummer.

I think some notice should now be taken by the Committee of Management of Mr. Holmes' continued absence from the Hospital. I understand Mr. Holmes has not discharged the

${ }^{24}$ Ballabriga, 'One Century of Pediatrics in Europe', in Nichols, et al. (eds), History of Pediatrics, p. 8.

25 Helen and Andrew Barlow, Sir Thomas Barlow, Bt. (London: Dawsons, 1965), p. 14. 


\section{Education and Research at the Paediatric Hospitals}

duties of his post for several months, and although Mr. Smith has been most punctual in his attendance, both on Mr. Holmes' account as well as his own, such an arrangement ought not, I think, to be indefinitely prolonged. ${ }^{26}$

Before becoming full surgeon at St. George's Holmes had carried out his duties at Great Ormond Street most energetically. His later lack of concern made no difference to his career for he went on to be as successful in his own sphere as Barlow and Jenner in medicine, except that he never received a knighthood. Service in a paediatric hospital had served as a stepping-stone to appointments in larger and more prestigious institutions.

Research in the diseases of children therefore tended to be discouraged by the want of special societies and journals for the presentation of findings, and also the lowly status of the discipline in the eyes of the medical hierarchy. Nothing illustrates this last point so well as the exclusion of paediatrics from the required subjects for qualifying as a physician in London. Compounding and reinforcing this position was the fact that the London teaching hospitals did not have organised paediatric departments with associated chairs or lectureships, although the London Hospital and University College Hospital had children's wards before 1870 . The others possessed beds for children and these institutions remained important sites, particularly for paediatric surgery, but without commitment to systematic instruction in the diseases of children.

For Charles West, who had received most of his medical education in France and in German countries where research was held in higher regard, the study of disease was a high priority. Before the foundation of Great Ormond Street his energies were expended in the type of research promoted since the beginning of the century by the Paris school of medicine involving clinical observation, the collection of statistics about incidence and outcome, and post-mortem examination to correlate lesions with pre-existing illness. He did not engage in the more innovative types of investigation involving the testing of hypotheses, nor does his fame rest on his initiating any new theory of disease, or making any unusual discovery as to the causation or treatment of illness. Instead his talents involved clinical acumen, unusual sensitivity and knowledge of how to deal with children, and complete familiarity with the contemporary medical literature so that he could advise contemporaries on all aspects of paediatrics from hospital management to the treatment of the most obscure disease. His Lectures on the Diseases of Infancy and Childhood, published in 1848, was acclaimed as the best textbook thus far produced by an English speaking author, for its clarity, organisation, scope, and also references to the work of continental writers 'often lending him a light for his direction through many intricacies' ${ }^{27}$ 'His knowledge of what others have done', this reviewer continued, 'is equalled only by his own extensive experience; and the results of both are combined in his valuable practical lectures now offered for the guidance of others'.

Most of the research conducted in British paediatric hospitals was of the type advocated by West, leading to reports on the nature of disease, its clinical history, treatment and prognosis. The collection of relatively large numbers of sick children as outpatients, and of smaller numbers as inpatients, encouraged the statistical assessment of various factors associated with illness, such as the commonest age of incidence, any sex bias (for

${ }^{26}$ G.O.S. Archives, Visiting Governors' Reports, 17 March, 1868.

27 'On the Diseases of Children', British and Foreign Medico-Chirurgical Review, 3 (1849): 406-32. 


\section{Elizabeth M. R. Lomax}

example, nocturnal urinary incontinence was found to be more frequent in male children), association with pre-existing illness (thus pericarditis and endocarditis were established as usually secondary to rheumatic fever) and, alternatively, the incidence of complications. Assessments of mortality rates and of residual morbidity were commonplace and essential to estimate the value of various treatments. Sometimes they indicated remarkable variation in the character and severity of affections. Epidemics of scarlet fever, for example, and even sporadic cases, could present as the most trifling illness on one hand or, on the other, as a fulminating infection.

Within the hospitals autopsies were performed whenever possible, which was frequently since families seem rarely to have objected. In an analysis of 117 medical cases treated at Pendlebury hospital in 1881 (in all 663 patients were discharged from, or died in, the medical wards that year), 71 improved or recovered while 46 died. ${ }^{28}$ Death was followed by autopsy in 31 cases, but not in the remaining 15 , because of refusal by the family in 3 instances, because the child died at home in 5 cases, and for no given reason in the remaining 7 , one of whom was a 21 -year-old lady probationer who died of typhoid fever presumed contracted from a patient. Some of the dissections were merely routine naked eye confirmations of diagnoses, while others went further involving the microscopic examination of tissue, again for purposes of confirmation, or to establish the micropathology of a disease, or because the lesions were unusual or unexpected.

One consequence of routine post-mortem examination was the discovery that tuberculosis was a far commoner affliction of children than previously suspected. Traditionally scrofula was perceived as a disease of children distinct from phthisis, or pulmonary consumption, which mostly afflicted young adults. Infancy was not associated with tubercular disease until the early nineteenth century when French clinical pathologists found that various viscera were the seat of tubercles in illness of previously unknown pathology. By mid-century, thanks to such findings, Rilliet and Barthez were asserting that internal or acute hydrocephalus was really tuberculous meningitis, that chronic peritonitis was also frequently of tubercular origin, and that wasting, or cachexia, in babies could have a similar underlying pathology. ${ }^{29}$ In his 1865 textbook, West used French research findings to illustrate the ubiquity and anatomical characteristics of tubercular deposits in children, even though isolated British reports of such phenomena did exist. ${ }^{30}$ West confined himself to the same French references in the 1874 edition of his text in part because this was little more than a reprint of the former edition. During the last two decades of the century, however, evidence from abroad was no longer essential since it was amply confirmed by domestic hospital findings. Furthermore, Koch's discovery of the causative bacillus in 1884 unified thinking about tuberculosis, scrofula and other aspects of tuberculosis of previously debatable origin. With reference to the tendency of tubercular lesions to be more widespread in children than in adults, in whom the lungs

\footnotetext{
${ }^{28}$ Abstracts of some of the Medical and Surgical Cases Treated at the General Hospital for Sick Children, Pendlebury, Manchester, during the Year 1881 (London: Pardon and Sons, 1882), pp. 1-19.

29 A. C. E. Barthez and F. Rilliet, Traité clinique et pratique des maladies des enfants (Paris: Germer-Baillière, 1854), Vol. III, pp. 364, 452, and 805. Barthez and Rilliet also discussed previous and contemporary research of diseases they described.

${ }^{30}$ Charles West, Lectures on the Diseases of Infancy and Childhood (Philadelphia: Henry C. Lea, 1866, from the 1865 English ed.), pp. 391-4.
} 


\section{Education and Research at the Paediatric Hospitals}

were commonly the only site of disease, the statistics provided by Ashby and Wright in 1899 were reasonably consonant with those supplied by Rilliet and Barthez (as quoted by West) nearly half a century earlier. ${ }^{31}$ (See table below.)

In 1909 David Forsyth, physician to the Evelina Hospital, argued that the Registrar General's returns of infant mortality due to tuberculosis seriously underestimated the number of deaths in infants from this cause. ${ }^{32}$ The official returns for England and Wales for 1905 reported that 5.1 per cent of infant mortality was due to tubercular disease. In the same year, this disease was confirmed at autopsy to have been responsible for 12.0 per cent of the mortality among infants treated at the Evelina Hospital. This figure excluded babies in whom tubercular lesions were found post-mortem but who had died from some other disease. Probably Forsyth was unjustified in assuming that the causes of hospital mortality should correspond with those in the community. Since tuberculosis was usually more chronic than some other potentially lethal ailments, such as diphtheria or acute pulmonary disease, there was perhaps more likelihood that its victims would end up in hospital. Furthermore, hospital physicians may have been biased in favour of admitting infants suffering from probable or possible tuberculosis. Nevertheless, Forsyth probably did not err much in claiming that tuberculosis frequently escaped diagnosis during life. In his opinion, deaths from this illness risked being certified as due to 'acute pulmonary disease', 'diarrhoea', 'marasmus', and 'convulsions', since such symptoms were so likely to exist during life. Only autopsy, as the French had originally insisted, could reveal the extensive ravages of tubercular disease among children.

Percent. incidence of tubercular deposits in various organs of children dying of tuberculosis.

\begin{tabular}{lcc}
\hline Organ affected & Incidence & Incidence \\
(Ashby and Wright) & (Rilliet and Barthez)
\end{tabular}

$\begin{array}{lcc}\text { Lungs } & 91 & 84 \\ \text { Bronchial glands } & 78 & 79 \\ \text { Mesenteric glands } & 65 & 46 \\ \text { Liver } & 63 & 22 \\ \text { Spleen } & 55 & 44 \\ \text { Intestines } & 55 \text { (small and large) } & 42 \text { (small) } \\ \text { Brain } & & 19 \text { (large) } \\ \text { Peritoneum } & 46 & 11 \\ \text { Kidney } & 44 & 27 \\ \end{array}$

Ashby and Wright's figures were based on 155 cases of tuberculosis dying in Pendlebury Hospital. Rilliet and Barthez's figures were based on 312 cases of tuberculosis aged from 1 to 15 years.

31 Ibid., p. 391; Henry Ashby and G. A. Wright, The Diseases of Children, Medical and Surgical (London: Longmans, Green, 1899), p. 230.

32 David Forsyth, 'Infant Mortality as Seen in a Children's Hospital: Being an Analysis of 1,202 Consecutive Infant Deaths in the Evelina Hospital for Sick Children', Proceedings of the Royal Society of Medicine, 2 (1909): 101-12. 


\section{Elizabeth M. R. Lomax}

Clinical acumen associated with pathological investigation scored its most renowned success in the delineation of infantile scurvy. ${ }^{33}$ In De Rachitide (1650), the English physician, Francis Glisson, had described scurvy as sometimes associated in infants with rickets although a distinct disease entity. ${ }^{34}$ But whereas rickets was commonplace enough, clear cut scurvy was probably very rare in babies since, during the next 200 years, British paediatric writers made no further definite reference to this entity. Occasionally, however, they described scurvy in older children in whom the disease resembles the adult form rather than that occurring in infants. ${ }^{35}$ Perhaps the peculiar form scurvy takes in children under the age of three years went unrecognised; more likely the disease was rare because prolonged breast feeding was practised. If so, then infantile scurvy should have surfaced when bottle feeding and proprietary foods began to displace suckling, which Thomas Barlow, and the wisdom of hindsight, allow us to see is what happened.

By the second half of the nineteenth century the traditional perception of rickets, as a chronic illness not usually becoming manifest before the second year of life, was being complicated by reports of an acute form of rickets occurring in early infancy and usually in artificially fed babies. Salomon Stiebel in 1854, then Julius Moeller in 1859, drew attention to this acute illness in which the baby became restless and irritable, broke out in sweats particularly of the head and neck, had a rapid pulse, diarrhoea alternating with constipation, and an enlarged abdomen while the rest of the body became emaciated. ${ }^{36}$ In the next stage of illness, the baby would cease to move its legs and, if they were touched, would shriek in apparent extreme pain. German physicians tended to accept the new entity of 'acute rickets', or 'Moeller's disease', while British ones mostly continued to adhere to the classical concept of rickets as a chronic illness. Debate continued until 1883 when Thomas Barlow, assistant physician at Great Ormond Street since 1876, presented a paper to the Medico-Chirurgical Society entitled: "On cases described as "acute rickets" which are probably a combination of scurvy and rickets, the scurvy being an essential, and the rickets a variable, element' ${ }^{37}$ Although unwieldy, the title accurately represented Barlow's interpretation which, as indicated by Leonard Wilson, was persuasive because Barlow was not satisfied with clinical suspicion but confirmed his hunch that scurvy was the culprit by post-mortem examination in three cases.

For actually the clinical diagnosis had been made some years earlier by Walter Butler Cheadle, also while on the medical staff of Great Ormond Street. (Cheadle served the hospital for twenty-three years, beginning in 1869.) In 1878 he described three cases of

${ }^{33}$ For the history of infantile scurvy, see: Kenneth J. Carpenter, The History of Scurvy and Vitamin C (Cambridge: University Press, 1986), pp. 158-72; Alfred F. Hess, Scurvy, Past and Present (Philadelphia: J. P. Lippincott, 1920), pp. 10-15; Elizabeth Lomax, 'Difficulties in Diagnosing Infantile Scurvy before 1878', Medical History, 30 (1986): 70-80; George F. Still, 'Infantile Scurvy: Its History', Archives of Disease in Childhood, 10 (1935), pp. 211-18; Leonard G. Wilson, 'The Clinical Definition of Scurvy and the Discovery of Vitamin C', Journal of the History of Medicine, 30 (1975): 40-60.

${ }_{34}$ Francis Glisson, De Rachitide (London: Th. Roycroft, 1660, 2nd ed.), pp. 261-2.

35 For example, T. H. Tanner, Practical Treatise on the Diseases of Infancy and Childhood (London: Henry Renshaw, 1858), pp. 194-5, discussed the symptoms and treatment of scurvy in older children but made no special mention of the disease in infants.

36 Salomon Stiebel, 'Rachitis und Osteomalacie', in Rudolph Virchow's Handbuch der spec. Path. u. Therap., 1 (1854): 527-51; Julius Moeller, 'Ueber Akute Rachitis', Konigsb. med. Jb., 1 (1859): 377-9.

37 Thomas Barlow, 'On Cases Described as "Acute Rickets" which are Probably a Combination of Scurvy and Rickets, the Scurvy being an Essential, and the Rickets a Variable, Element', Medico-Chirurgical Transactions, 66 (1883): 159-220. 


\section{Education and Research at the Paediatric Hospitals}

scurvy associated with rickets in infants (two of these children were patients at Great Ormond Street and, in so far as can be ascertained, was the first British physician since Glisson firmly to diagnose infantile scurvy and discuss it in print. ${ }^{38}$ The accepted explanation of his perspicuity is that he became familiar with the clinical features of adult scurvy during a journey of exploration in Canada in 1862 and thus was well prepared to recognise similar, although not identical, illness in babies. ${ }^{39}$ Cheadle published another paper on infantile scurvy in 1882, but serious notice was not taken until Barlow presented his more complete study the following year. ${ }^{40}$ Clinically he added little to Cheadle's descriptions (as Barlow himself admitted) but made his decisive contribution through analysis of the underlying macropathology. Effusion of blood under the periosteum of long bones, particularly the femur, and in muscle in the three cases that came to autopsy clearly distinguished the disease from rickets, while compatible with a diagnosis of scurvy. Further reinforcing this diagnosis was the effectiveness of anti-scorbutic remedies, such as orange juice, in restoring the health of babies treated in time.

Barlow's analysis was based on 31 cases, of which 19 were derived from the medical literature. Of the latter, 11 were of German origin, and usually reported as cases of 'acute rickets', while the remaining 8 had been published in British medical journals. Samuel Gee had contributed 5 of these cases, under the classification of 'osteal or periosteal cachexia' of unknown origin. Another, the earliest British one reported, had been a patient at Great Ormond Street under the care of Thomas Smith whose account was published in 1876 under the title of 'haemorrhagic periostitis'. The other two were Cheadle's cases recognised as scurvy grafted on rickets. Barlow himself had treated 11 of the cases under analysis while the remaining one depended on a private report communicated to him by a surgeon, Mr. Shoppee. All three of Barlow's autopsies were on baby girls who had died at Great Ormond Street. The first was the above mentioned infant who had been under the care of Thomas Smith; the second was Barlow's own case first seen in the outpatient department; and the third was also admitted from outpatients but originally by a colleague, Dr. David Lees, who later transferred the case to Barlow.

The above brief account indicates the importance of the hospital base in enabling Barlow to perform critical autopsies, for of the three babies involved only one was originally under his care. Furthermore, his senior colleagues on the staff at Great Ormond Street, Gee, Cheadle and Thomas Smith, gave him access to their patients so enabling him to see more cases than would have been possible in exclusively private practice. By the 1880s Barlow was accepted by his colleagues as principal investigator rather than Cheadle who had seniority and had been the first, in 1878, to draw attention to the probable scorbutic nature of the illness. But Barlow seems to have been the more energetic and forceful personality, and also to have been the one to realise the need for pathological investigation and to perform all the crucial autopsies at Great Ormond Street.

\footnotetext{
38 W. B. Cheadle, 'Three Cases of Scurvy Supervening on Rickets in Young Children', Lancet, ii (1878): 685-7.

${ }^{39}$ F. John Poynton, 'Dr. Cheadle and Infantile Scurvy', Archives of Disease in Childhood, 10 (1935): 219-22, states that Cheadle had told him 'that in those wanderings he learnt much about adult scurvy ... [also] when he returned to London and was on the honorary staff of the Hospital for Sick Children, Great Ormond Street, he recognized the scurvy of infants....

40 W. B. Cheadle, 'Osteal or Periosteal Cachexia and Scurvy', Lancet, ii (1882): 48-9. Here he states seeing three more cases since 1878, two in the hospital at Great Ormond Street, and one in his private practice.
} 
Great Ormond Street was also the base for most of the research conducted by George Frederick Still in his elucidation of a chronic form of juvenile arthritis which became known as 'Still's disease'. Having qualified from Guy's Hospital in 1893, he became a house physician during which time he came under the influence of James Goodhart who was then consulting physician to the Evelina Hospital. ${ }^{41}$ Intrigued by the study of diseases of children, Still went from Guy's to Great Ormond Street where, after serving as house physician, he was appointed medical registrar and pathologist in 1894, and assistant physician in 1899. The same year he was appointed physician at King's College Hospital to be in charge of the newly formed department for diseases of children. In 1906 King's College elected Still as its first professor in the diseases of children. Although working exclusively as a paediatrician, Still developed an extensive and lucrative private practice while also remaining on the staff of Great Ormond Street for more than thirty years. When he retired from practice in 1937 he received the K.C.V.O. and in retrospect is considered by many as the 'father' of British clinical paediatrics.

His most original research was performed soon after qualifying while a junior member of the Great Ormond Street medical staff. His monograph on 'A form of chronic joint disease in children', was presented to the Medico-Chirurgical Society in 1896, and his other seminal work on the organism responsible for posterior basic meningitis in infants was published the following year. ${ }^{42}$ The monograph on chronic arthritis was based on 22 cases almost all of whom were patients at Great Ormond Street. Still's observations on posterior basic meningitis were all made when he was registrar at Great Ormond Street where the babies were under the care of Drs. Barlow, Lees and Penrose. He considered it important to distinguish this illness from tuberculous meningitis and from suppurative meningitis secondary to other infection (both more likely to be fatal than the posterior basic form), and thought it might be akin to, if not identical with, epidemic cerebro-spinal meningitis (later to be characterised as meningococcal meningitis). In many cases he isolated a diplococcus which he thought responsible for the meningeal symptoms but was unable to be more specific. Early in the twentieth century the extended use of lumbar puncture to collect samples of cerebro-spinal fluid expedited the recognition of the various organisms that could cause meningitis, and the disease was subsequently differentiated according to the organism responsible rather than the supposed site of infection.

More speculative research was also occasionally undertaken. August Schoepf Merei, a Hungarian born physician who had settled in Manchester after the 1848 uprisings in his own country, was assisted by James Whitehead, surgeon to the Lying-in Hospital and lecturer in obstetrics, in forming the Clinical Hospital for Diseases of Children with the financial support of a local German merchant, Salis Schwabe. ${ }^{43}$ As soon as the hospital for outpatients opened, in 1856, Merei and Whitehead launched an investigation of early physical development on the principle that infants exhibiting growth retardation would be

41 D.N.B.; Hugh Thursfield, 'In Memoriam, George Frederick Still, 1868-1941', Archives of Disease in Childhood, 16 (1941): 147-9; 'Obituary, George Frederick Still', Lancet, ii (1941): 56-7.

42 G. F. Still, 'On a Form of Chronic Joint Disease in Children', Medico-Chirurgical Transactions, 80 (1897): 47-59; 'The Bacteriology of the Simple Posterior Basic Meningitis of Infants', Transactions of the Pathological Society, London, 49 (1897-98): 313-27.

43 The influence of foreign merchants and physicians on paediatric hospital development in Manchester is discussed by John V. Pickstone, Medicine and Industrial Society: A History of Hospital Development in Manchester and its Region, 1752-1946 (Manchester: University Press, 1985), pp. 118-20. 


\section{Education and Research at the Paediatric Hospitals}

more liable to subsequent illness such as rickets, a disease then considered of unusually high incidence in the Manchester area. Previously, as James M. Tanner has shown, researchers, particularly in France, had recorded height and head circumference in babies, but the Merei and Whitehead investigation seems to have been the earliest to attempt to establish several measures of early physical development and, in effect, to set up a longitudinal study of growth and its relation to disease. ${ }^{44}$ But the results were never published, except in the early annual reports of the small and almost unknown Clinical Hospital, and so never had the chance to reach even national medical awareness.

Merei had elucidated his interest in early growth in On the Disorders of Infantile Development and Rickets, published in 1855. Whitehead was a fitting collaborator for he had already undertaken a statistical inquiry into the age of menarche of young Manchester women and, after Merei's death in March, 1858, continued their investigation and described the findings in the first 50 pages of the Third Report of the Clinical Hospital, $1859 .{ }^{45}$ As Whitehead explained, the objectives were to ascertain:

1st-The laws of physical development, as indicated by the age at which the teething process commences, and that at which it is finally accomplished; the growth of the bony structures, as shown by the age at which that of the skull is completed [closure of the posterior fontanelle was the measure used]; the age at which the faculty of walking is attained: all in a state of health. 2nd-The manner in which one or more of these processes may be delayed by morbid agencies, and which of such agencies is the most commonly operative in its interference with the natural efforts. ${ }^{46}$

Children of so called 'good' development were used to establish normal criteria. These children were those originally brought to the clinic for acute disorders (as opposed to chronic ones) or for minor local ailments, whose bodily development looked good, who had no past history of serious ailments, and whose parents were healthy. At the other extreme, children of 'bad' development were those whose 'health has been deranged by inherited weakness or tendency to disease, by want of due supply of breast milk, by faulty diet, poverty, unhealthy locality, or neglect' ${ }^{47}$ More precise criteria were not given for this group so one can only assume that they were puny, sickly looking, perhaps listless, and had an unfavourable past history. Development was considered good in 1,030 children, bad in 615, and 'medium' in 541. This last set consisted of children who did not quite belong to either of the other two groups and were ignored in the final assessments.

Tooth eruption was scored in 763 children of good development and in 435 assigned to the bad group. In the former set, 79 per cent had at least one tooth by the age of 9 months, while at the same age only 37 per cent of the poorly developed babies had cut a tooth. At the age of 2 years, 88 per cent of the first group had completed dentition, whilst only 22 per cent of the others had finished teething. In the better developed group of children, Whitehead found the anterior fontanelle to be closed at an average age of 14 months, but

\footnotetext{
44 James M. Tanner, A History of the Study of Human Growth (Cambridge: University Press, 1981), pp. 254-60.

45 James Whitehead, On the Causes and Treatment of Abortion and Sterility (London: Churchill, 1847); an analysis of his inquiry into the age of menarche may be found in Tanner, History of the Study of Human Growth, pp. 290-1.

46 James Whitehead, Third Report of the Clinical Hospital, Manchester (London: Churchill, 1859), p. 20.

47 Ibid.
} 


\section{Elizabeth M. R. Lomax}

with a spread of 7 to 22 months. In 95 per cent of the poorly developed babies the anterior fontanelle was still open at 16 months, and remained unclosed in 70 per cent at 20 months. No mean was established for this group since in some complete closure had not yet been effected by 3 years of age. Similarly, the age at which walking began varied considerably between the two groups. In the superior set, 98 per cent were ambulant by the age of 18 months, whereas this was true for only 54 per cent of the poorly developed children at the same age.

The babies of 'good' development achieved the milestones of teething, anterior fontanelle closure, and walking on average at about the same ages as modern children. Merei and Whitehead had not included measures of height and weight in their format, so their study provides no direct evidence as to the size of the children surveyed. Head and chest circumference were estimated; at birth head circumference averaged out at about 13 $3 / 4$ inches, while the chest averaged out at about eight-tenths of an inch less. From then on both increased almost in parallel, with the chest growing slightly faster, so that both measures would be equal, at about 19 inches, by three and a half years of age. In poorly developed children equality was not usually reached until much later, with a mean of about five and a half years. Not until the seventh year did all the children observed display chest girth in excess of head circumference.

Chest circumference is not usually evaluated nowadays because of the variation in size due to breathing. Nevertheless, by modern standards even the children of 'good' development in the Manchester study seem to have been narrow chested. Between the ages of 21 and 24 months, 60 children in this group had an average chest measurement of 17.85 inches. In contrast, according to a recent American study, the chest circumference of children at two years of age averaged at 19.5 inches. The most likely reason for this difference is that Whitehead's subjects were much smaller than their modern counterparts. Supporting this view is James Tanner's analysis of Cowell's survey, and also Horner's, of height in children working in Lancashire factories during the 1830s. Tanner explains that these children were 'quite extraordinarily small by present day standards', with mean heights at about the modern third centile from eight to ten years of age. ${ }^{48}$ As babies they must also have been unusually small and so probably were even the healthy children in the Whitehead study.

Merei and Whitehead's investigation was intended for practical purposes: to establish norms of early development that could then be used to detect growth retardation, and also to demonstrate that children of poor development, particularly those with narrow chests, were unusually liable to scrofula, tuberculosis, and rickets. At about the same time, Franz P. Liharzik, physician at the Children's Hospital in Vienna, was also measuring head and chest circumferences in children aged from birth to sixteen years. ${ }^{49} \mathrm{His}$ aim was also to show the connection between poor chest development and chronic illness such as scrofula and rickets. Liharzik published his earliest findings in 1858, and then continued with more complex measures and ratios through the 1860s. As far as can be made out, Liharzik's values became more dubious, organized to fit his preconceptions of ideal growth, as time wore on. But his developmental data was reproduced and discussed in Karl Vierordt's

\footnotetext{
48 Tanner, History of the Study of Human Growth, p. 156.

49 Ibid., p. 64; Edith Boyd, Origins of the Study of Human Growth (University of Oregon Health Sciences Center Foundation, 1980), p. 446.
} 
influential 1877 review of growth studies, whereas no mention was made of Merei and Whitehead's efforts. ${ }^{50}$ Nor was it until the late 1870 s that the physical development of infants began to attract lasting attention as a topic of research.

The first reference in the records of the Birmingham Children's Hospital to any specific investigation was in 1881, as indicated by Rachel Waterhouse, when one of the hospital physicians, John B. Welch, reported to the management committee that Dr. Ballard, who was prosecuting a national investigation into the causes of infantile summer diarrhoea, wished to use facilities at the Children's Hospital. ${ }^{51}$ The original idea was to reopen one of the closed wards to admit babies suffering from diarrhoea and, when necessary, their mothers also. Initially, the management committee rejected Welch's request for financial reasons since the hospital would bear the costs of running the ward. But the medical staff persisted and the senior physician, Thomas Heslop, offered to contribute $£ 25$ or $£ 30$ towards the necessary expenditure. ${ }^{52}$ Finally the managing committee agreed to the project so long as one of the already open wards was used for the project. Babies were admitted for the study during the summer months of 1881 , and again in 1882 .

Edward Ballard worked as medical inspector for the Privy Council and for the Local Government Board from 1871 until 1890. The investigation of infantile summer diarrhoea was undertaken for the Local Government Board, begun in 1880, and the first report published in $1889 .{ }^{53}$ (Ballard continued the study until his death in 1897 but never published a second report. $)^{54}$ It was a vast undertaking, beginning with a study of summer diarrhoea in Leicester, then extending to other cities and localities, and involving children's hospitals. Among the hospitals partaking in the inquiry were, the Birmingham Children's Hospital with Welch as clinician in charge, Pendlebury Hospital with Henry Ashby as investigating physician, the Victoria Hospital for Children at Chelsea, and Leicester General Infirmary. The hospitalized babies could be more closely monitored than those left in their own homes and the report reveals attempts to find and culture microorganisms in both blood and stools. Unfortunately, bacteriological examination was not performed on the spot (presumably for lack of facilities and expertise at the hospitals). Instead the specimens were sent to Dr. Edward Klein, a Hungarian physician, trained in Vienna, who had been invited by Sir John Simon to work for the Local Government Board and was also lecturer in histology and bacteriology at the medical school of St. Bartholomew's Hospital. ${ }^{55}$ The specimens often took days to reach Klein in London. However, in several samples he found micrococci, in a few instances he managed to culture them, but in no instance did inoculation of the culture into guinea pigs cause any ill effects whatever.

Lacking evidence of bacteriological specificity, Ballard was led to conclude that air or water polluted by microbes was the best provisional explanation for epidemics of summer

\footnotetext{
${ }^{50}$ Karl Vierordt, 'Physiologie des Kindesalters', in C. Gerhardt (ed.), Handbuch der Kinderkrankheiten (Tübingen: H. Laupp, 1877), pp. 53-224.

${ }_{51}$ Rachel Waterhouse, Children in Hospital: A Hundred Years of Child Care in Birmingham (London: Hutchinson, 1962), p. 76.

52 Birmingham Children's Hospital Archives, Minutes of Committee of Management, 17 June, 1881, record of 'special meeting with medical staff'.

53 Seventeenth Annual Report of the Local Government Board, 1887-1888: Supplement in Continuation of the Report of the Medical Officer for 1887: Diarrhoea and Diphtheria (London: H.M.S.O., 1889).

54 'Obituary-Edward Ballard, M.D., F.R.CP., Lond. F.R.S.', Lancet, i (1897): 342-3.

55 'Obituary-E. E. Klein', British Medical Journal, i (1925): 388-9.
} 
diarrhoea. As he stated: 'the essential cause of diarrhoea resides ordinarily in the superficial layers of the earth, where it is intimately associated with the life processes of some micro-organism not yet detected, captured, or isolated' ${ }^{56} \mathrm{He}$ conjectured that under suitable atmospheric conditions the microorganism became airborne, and capable of invading food, water and even the surface of the human body. Actual illness, he believed, was due to a virulent chemical poison produced by the microbe during its life cycle.

Although influential in England at the time of its publication, Ballard's report has been ignored by most historians, with the notable exception of Deborah Dwork, who has discussed the investigation in War is Good for Babies. ${ }^{57}$ After 1880 and through the turn of the century, British physicians were well aware of Ballard's prolonged investigation of infantile diarrhoea to which several references were made in the medical journals. ${ }^{58}$ However, since his account was a supplement to the 1887 Report of the Medical Officer for the Local Government Board, it was not published with the 1887 report but independently, and thus did not have the wide circulation achieved by the annual local government reports.

As anticipated by their medical founders, the paediatric hospitals became bases for clinical research. The more energetic or inquiring members of the medical staff undertook studies in the natural history of disease and associated changes in pathology with considerable success. John A. Davis has suggested that 'Britain may have led the world in the art of paediatric medicine', although, in my opinion, France posed a strong challenge to that title. ${ }^{59}$ However, although at the beginning of the century it was the Parisian school of medicine that had emphasized the need to avoid theory and concentrate on clinical findings, morbid anatomy and statistical analysis, this latter more pragmatic approach ended up being more consistently carried out by the British, probably because the empirical requirement not to go beyond the facts, not to speculate, was more traditional with them than with the French. Thus, in the late 1870s, Marie Jules Parrot advanced the theory that rickets was a manifestation of congenital syphilis and supported this thesis with the assertion that the bony changes were the same in both diseases. ${ }^{60}$ By 1881 Parrot had convinced himself that most cases of rickets were instances of degenerative, or transformed, syphilis. This conception fitted in with the larger theory, with a long history among French clinicians, that syphilis was a hereditary degenerative disease, which when passed on to the offspring could manifest itself in other related forms of illness such as scrofula or rickets.

A large number, perhaps even the majority, of French physicians were unconvinced by the notion that heredity could induce the transformation of disease as suggested by Parrot, and previously by Antoine Portal, Jean Guillaume Lugol and Prosper Lucas. ${ }^{61}$ But British

\footnotetext{
56 Seventeenth Annual Report of the Local Government Board . . Diarrhoea and Diphtheria, p. 7.

57 Deborah Dwork, War is Good for Babies and Other Young Children: A History of the Infant and Child Welfare Movement in England 1898-1918 (London: Tavistock, 1987), pp. 36-8 and 224.

58 For example, 'Editorial on Infantile Diarrhoea', Lancet, ii (1885): 391; 'Islington Medical SocietyPresentation by Dr. Ballard', Lancet, i (1889): 1247.

59 J. A. Davis, 'British Pediatrics', in Nichols, Ballabriga, and Kretchmer (eds), History of Pediatrics 1850-1950, pp. 31-6, on p. 34.

${ }^{60}$ M. J. Parrot, 'The Osseous Lesions of Hereditary Syphilis', Lancet, i (1879): 696-8; 'Marie Jules Parrot', in Dictionnaire encyclopédique des sciences médicales (Paris: Masson, Asselin, 1885), Ser: 2, XXI, p. 488.

61 Antoine Portal, 'Considerations on the Nature and Treatment of some Hereditary or Family disease', London Medical and Physical Journal, 21 (1809): 281-96; Jean Guillaume Lugol, Researches on Scrofulous Diseases, trans. A. Sidney Doane (New York: 1847); Prosper Lucas, Traité philosophique et physiologique de l'hérédité naturelle, 2 vols. (Paris: J. B. Baillière, 1850).
} 


\section{Education and Research at the Paediatric Hospitals}

physicians seem to have objected even more strongly to a belief so contradictory to the cherished notion of disease specificity. In 1881, The medical correspondent for the British Medical Journal in Paris was heavily sarcastic in his denunciation of Parrot's views on the relation of syphilis to rickets. ${ }^{62}$ However, in retrospect this report demonstrates not only the merits of scepticism but also its dangers. For the writer, having ridiculed Professor Parrot, continued in the same vein with reference to Louis Pasteur; 'When a man has a hobby, there is no knowing how far he will go with it; and this may be applied to $M$. Pasteur, who sees germs everywhere'. Particularly silly, according to the correspondent, was Pasteur's conclusion, after numerous experiments with rabid animals, that the unknown virus causing rabies was chiefly located in the brain.

The above anecdote is an example of rather widespread British unwillingness to enunciate or accept new theories until very convincingly demonstrated to be likely. In many ways this was an advantage in the nineteenth century, when speculation was still rife, and when British empiricism acted as a corrective to sometimes excessive continental theorizing. On the clinical side British paediatricians carefully reported on the incidence, natural history, and pathology of various diseases, so adding to ontological knowledge. Less remarkable, as indicated by Davis, were their contributions to clinical science, apart from that of bacteriology. ${ }^{63}$ Here the impediments were lack of scientific training as medical students and lack of access to university laboratories as practising physicians. Edward Klein, mentioned above as having performed bacteriological examination of stools for Edward Ballard, is considered, together with Burdon Sanderson, as the earliest to specialize in bacteriology and to have done more than anyone else to develop the subject in England. He was trained in Vienna. As far as laboratories were concerned, they would not be found in the financially strapped, clinically oriented special hospitals, and the larger teaching hospitals would not see the need to encourage paediatric science until the twentieth century.

Finally, one practical educational benefit derived from the establishment of hospitals for children should be mentioned, that is the appearance of paediatric textbooks. Until 1848, when Charles West's Lectures on the Diseases of Infancy and Childhood was published, British doctors had to be content with outdated books directed more to parents than to physicians or else read, or find translations of, French paediatric texts. At that time the best known English work was still Michael Underwood's Treatise on the Diseases of Children, first published in 1774. Underwood died in 1820 but his book continued to be published posthumously. The ninth edition of 1842 was heavily annotated by Samuel Merriman and Marshall Hall (with extra notes by John Bell in the American edition), making for fascinating reading to any historian but which can only have been utterly confusing to anyone seeking medical information. The only other attempt at a comprehensive textbook, as opposed to manuals of child care and management, was A Practical Treatise on the Management and Diseases of Children (1836) by Richard T. Evanson, Professor of Medicine, and Henry Maunsell, Professor of Midwifery in Dublin.

After the creation of special hospitals, however, there was no further shortage of British textbooks. The success of West's Lectures on the Diseases of Infancy and Childhood has already been noted, but it should be remembered that, when originally published in 1848 ,

62 'Special Correspondence-Paris', British Medical Journal, ii (1881): 138.

${ }^{63}$ Davis, 'British Pediatrics', in Nichols,Ballabriga and Kretchmer (eds), History of Pediatrics, pp. 34-5. 


\section{Elizabeth M. R. Lomax}

this work was based on experience mainly gained from patients seen at the Dispensary for Children at Waterloo Bridge Road. Critical was the capacity to observe relatively large numbers of sick children, whether in- or outpatients was of lesser importance. During the second half of the century almost every new paediatric hospital was the source of information, and inspiration, for at least one paediatric text. The inspiration, or stimulus, was the common requirement in the larger hospitals for attending physicians to teach, hence many texts were first written as lectures. Given the early and persistent requirement of lecture courses to students and physicians, Great Ormond Street nurtured various authors apart from West, including the physicians Thomas Hillier and Walter Butler Cheadle and the surgeons Timothy Holmes and Edmund Owen. ${ }^{64}$ At the Evelina, James F. Goodhart compiled a very popular Student's Guide to the Diseases of Children (1885), later with the assistance of G. F. Still to undergo enlargement and repeated editions. At the East London Hospital for Children, Eustace Smith wrote several paediatric texts including The Wasting Diseases of Infants and Children (1868), Clinical Studies of Diseases of Children (1876) and A Practical Treatise on Diseases of Children (1884). Also based at the same hospital, Horatio Bryan Donkin authored a Diseases of Children (1893). Ashby and Wright of Manchester originally published in 1889 a combined medical and surgical text to which frequent reference has been made here. Physicians at Edinburgh were also active with John Thomson's Guide to the Clinical Examination and Treatment of Sick Children (1898) and James Carmichael's Diseases in Children (1892). Although paediatrics was not yet a recognised speciality, the textbooks sold reasonably well, since most of the above underwent more than a single edition. For some knowledge of the diseases of children, even if originally gleaned from books, was essential to general practice and, in comparison to most nineteenth-century French texts, the British ones were most practically oriented.

\footnotetext{
64 T. Hillier, Diseases of Children (London: Walton, 1868); W. B. Cheadle, On the Principles and Exact Conditions to be Observed in the Artificial Feeding of Infants ... (London: Smith, Elder, 1889); T. Holmes, The Surgical Treatment of the Diseases of Infancy and Childhood (London: Longmans, Green, Reader, and Dyer, 1868) and Edmund Owen, The Surgical Diseases of Children (London: Cassell, 1885).
} 